\title{
TINJAUAN FIKIH MUAMALAH TERHADAP PRAKTIK TRANSAKSI MENGGUNAKAN KOIN DI FLOATING MARKET LEMBANG BANDUNG
}

\author{
Muhamad Hiqal Fahrurrozi ${ }^{1}$, Rizqi Rivaldi ${ }^{2}$, Muhammad Faturrachman ${ }^{3}$ \\ ${ }^{1}$ Prodi Hukum Ekonomi Syariah Universitas Islam Bandung, hiqalfahrurrozi@ gmail.com \\ ${ }^{2}$ Prodi Hukum Ekonomi Syariah Universitas Islam Bandung, rrizqi97@gmail.com \\ 3 Prodi Hukum Ekonomi Syariah Universitas Islam Bandung, f898565@gmail.com
}

\begin{abstract}
Now, many people are just only looking for something that is current and unique and ignore the local culture. This is different from the market in Bandung, namely Floating Market Lembang, which uses coins as a medium of exchange in its transactions. This is a new phenomenon in the field of muamalah, so it requires the study of Muamalah Jurisprudence to review its validity. The main problems in this study include: (1) how is the practice of buying and selling with the coin exchange tool in the Floating Market Lembang? (2) what is the view of Jurisprudence regarding the practice of buying and selling with a coin exchange tool. The purpose of this study was to find out about the validity of the practice of buying and selling with a coin exchange tool in the Lembang Floating Market in terms of the study of Muamalah Jurisprudence. The results of this study indicate that the practice of buying and selling with a coin exchange tool is in accordance with Islamic law, which has fulfilled the harmony and its requirements in buying and selling. In addition, the principles of muamalat have been implemented, namely the principle of willingness, does not contain the element of gharar and maintains sharia maqasid. The legal status of buying and selling in this Floating Market is legal. However, this validity only applies to the Lembang Floating Market and not as a whole for the general public.
\end{abstract}

Keywords: Fiqh Muamalah, Buying and Selling, Coins 


\begin{abstract}
ABSTRAK
Di zaman sekarang banyak orang yang hanya mencari sesuatu yang kekinian dan unik saja dan mengabaikan budaya daerahnya setempat. Hal ini berbeda dengan pasar yang berada di Bandung yaitu Floating Market Lembang, yang menggunakan koin sebagai alat tukar dalam bertransaksinya. Hal ini merupakan fenomena baru dalam bidang muamalah, sehingga memerlukan kajian Fikih Muamalah untuk meninjau keabsahannya. Masalah utama dalam penelitian ini meliputi: (1) bagaimana praktik jual beli dengan alat tukar Koin di Floating Market Lembang? (2) bagaimana pandangan Fikih Muamalah tentang praktik jual beli dengan alat tukar koin. Tujuan penelitian ini adalah mengetahui tentang keabsahan praktek jual beli dengan alat tukar koin di Floating Market Lembang ditinjau dari kajian Fikih Muamalah. Hasil dari penelitian ini menunjukkan bahwa praktek jual beli dengan alat tukar koin sesuai dengan hukum Islam, yaitu telah memenuhi rukun dan syaratnya dalam jual beli. Selain itu, telah menerapkan asas-asas muamalat yaitu asas kerelaan, tidak mengandung unsur gharar dan menjaga maqasid syariah. Status hukum jual beli di Pasar Floating Market ini ialah bersifat sah. Namun, keabsahan ini hanya berlaku untuk Floating Market Lembang dan bukan berlaku secara keseluruhan untuk masyarakat umum.
\end{abstract}

Kata Kunci: Fikih Muamalah, Jual Beli, Koin 


\section{PENDAHULUAN}

Di era dewasa ini banyak sekali hal yang menarik perhatian tentang jual beli. Dimana jual beli tidak hanya bertujuan untuk memenuhi kebutuhan sehari-hari, namun berkembang menjadi sarana mencari keuntungan semata hingga kepada hal-hal yang bersifat memenuhi kepuasan. Hal ini boleh saja dilakukan, karena Islam tidak pernah membatasi manusia dalam melakukan jual beli.

Menurut Imam Nawawi sebagaimana yang dikutip Rachmat Syafe'i mengatakan bahwa jual beli merupakan pertukaran harta dengan harta dengan maksud untuk memilikinya. Sedangkan pengertian jual beli menurut Hendi Suhendi, ialah suatu perjanjian tukar menukar benda atau barang yang mempunyai nilai secara sukarela di antara kedua belah pihak, yang satu menerima benda-benda dan pihak lain menerimanya sesuai dengan perjanjian atau ketentuan yang telah dibenarkan syara' dan disepakati. Definisi jual beli ini sejalan dengan firman Allah bahwa jual beli harus didasarkan atas keinginan sendiri dan atas dasar suka sama suka, seperti yang tertuang dalam surat Al-Nisa ayat 29 yang berbunyi:

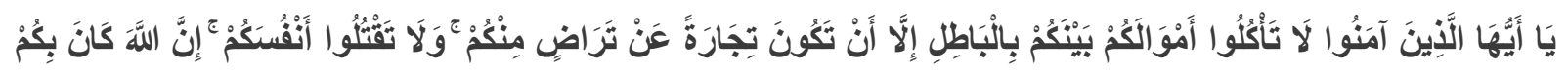

"Wahai orang-orang yang beriman! Janganlah kamu saling memakan harta sesamamu dengan jalan yang batil (tidak benar), kecuali dalam perdagangan yang berlaku atas dasar suka sama suka di antara kamu. Dan janganlah kamu membunuh dirimu. Sungguh Allah Maha Penyayang kepadamu”.

Dari ayat di atas menerangkan bahwa kita dilarang mengambil harta orang lain dengan jalan yang haram yang tidak sesuai syara', seperti riba, judi, ghasab, dan menipu. Akan tetapi, diperbolehkan mengambil harta orang lain dengan jalan perdagangan yang berdasar atas asas saling ridha dari kedua belah pihak dan selama masih tidak keluar dari koridor syara'.

Berkaitan dengan jual beli tentunya tidak terlepas dari alat pembayarannya yaitu uang. Para fuqaha mengemukakan bahwa "Uang adalah apa yang digunakan manusia sebagai standar ukuran nilai harga dan media transaksi pertukaran”. Sedangkan menurut Nur Rianto Al-Arif dalam bukunya Ekonomi Islam, mengatakan bahwa uang adalah sesuatu yang dapat diterima secara umum sebagai alat pembayaran dalam suatu wilayah tertentu atau sebagai alat untuk melakukan pembelian barang dan jasa.

Pada umumnya, hampir semua transaksi dalam perekonomian menggunakan uang sebagai mata uang atau alat tukar. Namun, bagaimana jika dalam sebuah transaksi yang menjadi alat tukar bukan berupa uang, melainkan koin. Hal ini seperti yang terjadi di Floating Market Lembang. Floating Market Lembang merupakan sebuah pasar yang berada di Kabupaten Bandung.

Didirikannya Floating Market dilator belakangi oleh keinginan dari pemerintah Kabupaten Bandung yang ingin melestarikan kembali makanan dan minuman tradisional. Terdapat 65 jenis kuliner yang khas, seperti pecel-pecelan, godog-godogan, minuman jamu, 
kopi, nasi liwet, nasi jagung, serabi yang dikemas dengan wadah tradisional yang ramah lingkungan, seperti batok kelapa, gelas dari bambu, gerabah, daun pisang, dan daun jati, yang mana menghindari pemakaian dari bahan plastik.

Selain itu tujuan didirikannya Floating Market ini ialah untuk mengingatkan kembali akan makanan tradisional di tengah-tengah perkembangan zaman. Dalam Floating Market ini tidak hanya makanan dan minimuan saja yang tradisional, melainkan penjual dalam Floating Market ini juga menggunakan pakaian busana adat tradisional.

Dalam pasar yang terletak di Kabupaten Bandung ini terdapat hal yang unik dalam proses transaksinya, yaitu menggunakan koin sebagai alat tukarnya. Koin yang digunakan ialah koin.

Dalam prakteknya, sebelum pembeli melakukan transaksi jual beli, pembeli diharuskan untuk menukarkan uang mereka dengan koin di tempat penukaran. Dalam penukarannya satu koin dihargai dengan senilai dua ribu rupiah. Sehingga, apabila pembeli hendak membeli makanan ataupun minuman di dalam Floating Market ini transaksinya harus dengan koin dan tidak diperkenankan menggunakan uang.

Untuk proses pembeliannya, setiap makanan atau minuman telah dipatok dengan harga koin, seperti misalnya, bakso dihargai dengan 4 (empat) koin, es teh dengan 2 (dua) koin, serabi dihargai dengan 4 (empat) koin, soto dihargai dengan 6 koin. Transaksi seperti ini telah terjadi di masyarakat Kabupaten Bandung khususnya di Floating Market Lembang sejak 22 April 2018.

Melihat fenomena tersebut menjadi hal yang baru di bidang muamalah. Jual beli dengan alat tukar berupa koin merupakan suatu transaksi yang aturan hukumnya pun belum banyak dibahas dalam Al-Qur'an dan Hadis Nabi. Sedangkan jual beli seperti ini dilakukan di masyarakat Kabupaten Bandung yaitu di Floating Market.

\section{LITERATUR REVIEW}

Kata jual beli terdiri dari dua kata, yaitu jual dan beli. Kata jual dalam bahasa Arab dikenal dengan istilah al-bay' yaitu bentuk mashdar dari bâ'a - yabî'u - bay'an yang artinya menjual. Adapun kata beli dalam bahasa Arab dikenal dengan istilah al-syirâ yaitu mashdar dari kata syara' yang artinya membeli. Dalam istilah fikih, jual beli disebut dengan al-bay' yang berarti menjual, mengganti, atau menukar sesuatu dengan sesuatu yang lain. Inti jual beli secara istilah ialah perjanjian antar dua pihak atau lebih dalam transaksi pemindahan kepemilikan atas suatu barang yang mempunyai nilai dan dapat terukur dengan satuan moneter.

Secara etimologi, jual beli diartikan sebagai pertukaran sesuatu dengan yang lain atau memberikan sesuatu untuk menukarkan sesuatu yang lain. Shalah ash-Shawi mengartikan jual beli dengan menukar harta dengan harta. Sementara Wahbah al-Zuhaily sebagaimana yang dikutip oleh Abdul Rahman Ghazaly, mengartikannya secara bahasa dengan "menukar sesuatu dengan sesuatu yang lain. Kata $a l-b a{ }^{\prime} i$ dalam Arab terkadang digunakan untuk 
pengertian lawannya, yaitu kata al-syira' (beli). Dengan demikian, kata al-ba'i berarti jual, tetapi sekaligus juga berarti beli.

Menurut Sayyid Sabiq sebagaimana yang dikutip oleh Idri, jual beli adalah pertukaran harta dengan harta atas dasar saling merelakan atau memindahkan milik dengan ganti yang dapat dibenarkan.Sedangkan pengertian secara syara' adalah tukar menukar harta dengan harta untuk memiliki dan memberi kepemilikan.

Jual beli sebagai sarana tolong menolong antara sesama umat manusia mempunyai landasan yang kuat dalam Al-Qur'an dan sunnah Rasulullah Saw. Terdapat beberapa AlQur'an, sunnah Rasulullah yang berbincang tentang jual beli, antara lain:

1) Surat Al-Baqarah ayat 275:

"Allah menghalalkan jual beli dan mengharamkan riba.... ".

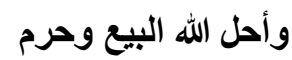

2) Surat al-Baqarah ayat 198:

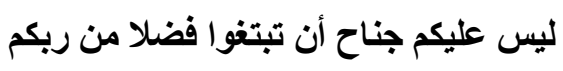

"Tidak ada dosa bagimu untuk mencari karunia (rezeki hasil perniagaan) dari Tuhanmu”.

Hadis yang diriwayatkan oleh al-Tirmizi, Rasulullah Saw bersabda:

"Nashr bin Ali menceritakan kepada kami, Abu Ahmad menceritakan kepada kami, Yahya bin Ayyub menceritakan kepada kami, ia berkata: Saya mendengar Abu Zur"ah bin Amr menceritakan, ia dari Abu Hurairah dari Nabi saw bersabda: "Janganlah sekali-kali kalian (cepat-cepat) berpisah di dalam jual beli, kecuali atas dasar saling rela merelakan.”

Hadis yang diriwayatkan al-Tirmizi, Rasulullah Saw bersabda:

"Pedagang yang jujur dan terpercaya sejajar (tempatnya di surga) dengan para Nabi, shaddiqin dan syuhada”.

Menurut bahasa, ijma' adalah ketetapan dan kesepakatan. Sedangkan menurut definisi Jumhur, ijmak merupakan kesepakatan ulama. Adapun dalil ijmak tentang jual beli, adalah bahwa ulama sepakat tentang halalnya jual beli dan haramnya riba.

\section{PEMBAHASAN}

Dalil kebolehan jual beli menurut ijma' ulama adalah telah sepakat bahwa jual beli diperbolehkan dengan alasan bahwa manusia tidak akan mampu mencukupi kebutuhan dirinya tanpa bantuan orang lain. Namun, bantuan atau barang milik orang lain yang dibutuhkannya itu harus diganti dengan barang lainnya yang sesuai. Oleh karena itu, hikmah dari jual beli itu sendiri dapat membantu manusia untuk kelangsungan hidupnya. 
Kebutuhan manusia untuk mengadakan transaksi jual beli sangat besar, dengan transaksi jual beli seseorang mampu untuk memiliki barang orang lain yang diinginkan tanpa melanggar batasan syariat. Oleh karena itu, praktek jual beli yang dilakukan manusia semenjak Rasulullah Saw., hingga saat ini menunjukkan bahwa umat telah sepakat akan disyariatkannya jual beli.

Dari ayat, hadist, dan ijma' ulama di atas diketahui bahwa jual beli diperbolehkan (dihalalkan oleh Allah) asalkan dilakukan dengan saling rela antara penjual dan pembeli. Hukum jual beli bisa menjadi haram, mubah, sunnah, dan wajib atas ketentuan sebagai berikut:

1. Hukum jual beli menjadi wajib pada saat darurat atau terpaksa yang sangat membutuhkan sekali terhadap makanan atau minuman sedang ia mampu untuk melakukan jual beli.

2. Hukum jual beli menjadi haram, jika menjual belikan sesuatu yang di haramkan oleh syara' seperti menjual babi.

3. Jual beli hukumnya sunnah apabila seorang bersumpah untuk menjual barang yang tidak membahayakan, maka melaksanakan yang demikian itu sunnah.

4. Jual beli dihukumi makruh, apabila transaksi dilakukan pada saat selesai.

Jual beli mempunyai rukun dan syarat yang harus dipenuhi, sehingga jual beli itu dapat dikatakan sah oleh syara'. Dalam menentukan rukun jual beli terdapat perbedaan pendapat ulama Hanafiyah dengan jumhur ulama.

Rukun jual beli menurut ulama Hanafiyah hanya satu, yaitu ijab (ungkapan membeli dari pembeli) dan kabul (ungkapan menjual dari penjual). Menurut mereka, yang menjadi rukun dalam jual beli itu hanyalah kerelaan (ridha/taradhi) kedua belah pihak untuk melakukan transaksi jual beli. Akan tetapi, karena unsur kerelaan itu merupakan usur hati yang sulit untuk di indra sehingga tidak keliatan, maka diperlukan indikasi yang menunjukkan kerelaan itu dari kedua belah pihak. Indikasi yang menunjukkan kerelaan tersebut menurut mereka tergambar dalam ijab dan kabul.

Akan tetapi, jumhur ulama menyatakan bahwa rukun jual beli itu ada empat, yaitu:

1. Ada orang yang berakad atau al-muta'aqidain (penjual dan pembeli).

2. Ada shighat (lafal ijab dan kabul).

3. Ada barang yang dibeli.

4. Ada nilai tukar pengganti barang.

Sedangkan, menurut ulama Hanafiyah, rukun jual beli yaitu orang yang berakad, dan barang yang dibeli, sedangkan nilai tukar barang termasuk ke dalam syarat-syarat jual beli bukan rukun jual beli.

Menurut Kompilasi Hukum Ekonomi Syariah, unsur jual beli ada tiga, yaitu:

1. Pihak-pihak. Pihak-pihak yang terikat dalam perjanjian jual beli terdiri atas penjual, pembeli, dan pihak yang terlibat dalam perjanjian tersebut. 
2. Objek. Objek jual beli terdiri atas benda yang berwujud dan benda yang tidak berwujud, yang bergerak maupun yang tidak bergerak, dan yang terdaftar maupun yang tidak terdaftar.

3. Kesepakatan. Kesepakatan dilakukan dengan tulisan, lisan dan isyarat, ketiganya mempunyai makna hukum yang sama. Ada dua bentuk akad, yaitu:

a. Akad dengan kata-kata, dinamakan juga dengan ijab kabul. Ijab, yaitu kata-kata yang diucapkan terlebih dahulu. Misalnya: penjual berkata: "Baju ini saya jual dengan harga Rp.10.000,-. Kabul, yaitu kata-kata yang diucapkan kemudian. Misalnya: Pembeli berkata: "Barang saya terima".

b. Akad dengan perbuatan, dinamakan juga dengan mu'athah. Misalnya: Pembeli memberikan uang seharga Rp. 10.000,- kepada penjual, kemudian mengambil barang yang senilai itu tanpa terucap kata-kata dari kedua belah pihak.

Dalam Islam, pada dasarnya setiap transaksi jual-beli adalah mubah (diperbolehkan) yaitu apabila terjadi kesepakatan antara pembeli dan penjual. Transaksi apa pun tetap diperbolehkan, kecuali transaksi yang dilarang oleh Rasulullah Saw.

Keseluruhan ajaran Islam merupakan satu kesatuan yang saling berkaitan dan bertujuan untuk membawa kebahagiaan dan kesejahteraan hidup manusia di dunia dan akhirat. Selain itu juga tuntutan umat Islam untuk menjalankan praktek ekonomi yang lebih sesuai dengan nilai-nilai ajaran Islam.

Dalam perkembangannya transaksi jual beli semakin bervariasi dari waktu ke waktu, dimana banyak di antara mereka yang hanya mencari kekinian dan unik saja, namun mengabaikan budaya daerah setempatnya. Hal ini berbeda dengan pasar yang baru beroperasi yang berada di Hutan Kota Rajawali yaitu Floating Market Lembang. Berdasarkan hasil penelitian di Floating Market Lembang dapat diketahui praktek jual beli dengan alat tukar koin, yang kemudian akan dipadukan dengan buku-buku yang mengkaji tentang jual beli, alat tukar dan kaidah jual beli yang berkaitan dengan alat tukar.

"Qutaibah menceritakan kepada kami, Husyaim menceritakan kepada kami dari Abu Bisyr dari Yusuf bin Mahak dari Hakim bin Hizam berkata: Saya bertanya kepada Rasulullah Saw: "Seorang lelaki datang kepadaku dan dia minta kepadaku suatu barang yang belum saya miliki, apakah saya boleh membeli di pasar, kemudian saya menjualnya kepadanya? Rasulullah Saw bersabda: "Janganlah engkau menjual sesuatu yang belum engkau miliki." (HR.At-Tirmidzi).

Hadits di atas berkenaan dengan larangan jual beli barang yang tidak dimiliki oleh penjual ketika akad dilangsungkan. Rasulullah melarang cara berjualan seperti ini.

Dari beberapa analisis di atas, dapat disimpulkan bahwa barang yang menjadi objek jual beli di Floating Market Lembang ini sudah memenuhi syarat untuk melakukan transaksi jual beli sebagaimana yang terdapat dalam kaidah-kaidah hukum Islam. Dimana objek yang dijadikan jual beli telah memenuhi beberapa syarat, di antaranya seperti; suci, bermanfaat, ada pada saat diperjualbelikan, milik sendiri, dan dapat diserahkan pada saat akad berlangsung atau pada waktu transaksi dilakukan. 
Mengenai Shighat (ijab dan kabul) ialah pernyataan kehendak para pihak (pembeli dan penjual) dalam tercapainya kata sepakat dalam suatu perjanjian. Dalam bertransaksi jual beli di Floating Market Lembang ini, cara yang dipergunakan oleh penjual dan pembeli dalam menyatakan ijab dan kabul adalah dengan pengucapan yang jelas. Artinya penjual dan pembeli dalam pengucapan lafal ijab dan kabul melalui kata-kata. Untuk dapat dikatakan sah, maka shighat harus memenuhi syarat shighat sebagaimana yang terdapat dalam jual beli. Para ulama fikih mengemukakan bahwa syarat ijab dan kabul itu sebagai berikut:

a. Orang yang mengucapkannya telah baligh dan berakal.

Bahwa para pihak yang melakukan transaksi jual beli di Floating Market Lembang pada umumnya telah baligh, hal ini ditandai dengan usia para pihak yang telah mencapai 17 tahun ke atas sehingga telah memiliki kecakapan hukum. Selain itu para pihak yang bertransaksi juga telah berakal yang ditandai dengan pihak penjual yang mampu menetapkan harga makanannya dengan harga koin, dan pihak pembeli yang telah mampu membeli makanan dan minuman sesuai dengan yang diinginkan.

b. Adanya kesesuaian antara ijab dengan kabul.

Dalam transaksi di Floating Market Lembang penerapan ijab dan kabul telah sesuai. lafal ijab yang dikatakan penjual berupa "Saya jual bubur ini dengan harga 2 (dua) Koin (sepuluh ribu rupiah)". Sementara lafal kabul yang dikatakan pembeli berupa "Saya beli Bubur itu dengan 2 (dua) Koin (sepuluh ribu rupiah).

c. Ijab dan kabul itu dilakukan dalam satu majelis.

Bahwa Ijab dan kabul dalam proses transaksi yang terjadi di Floating Market Lembang ini dilakukan dalam satu tempat yaitu di Floating Market Lembang. Hal ini dapat dilihat dari pihak penjual dan pembeli yang saling menyerahkan makanan tradisional dan koin pada saat transaksi berlangsung.

Dari beberapa analisis di atas, dapat disimpulkan bahwa shighat yang dilakukan para pihak dalam bertransaksi di Floating Market Lembang ini sudah memenuhi syarat sebagaimana yang terdapat dalam kaidah-kaidah hukum Islam. Dimana orang yang mengucapkannya telah baligh dan berakal, adanya kesesuaian antara ijab dan kabul, serta dilakukan dalam satu majelis.

Alat tukar menjadi unsur penting dalam suatu transaksi jual beli. Dalam prakteknya yang menjadi alat transaksi di Floating Market Lembang ini bukanlah uang melainkan dengan koin. Koin ialah koin yang terbuat dari tanah liat, dan berwarna kecoklatan. Dalam Floating Market ini satu koinnya dihargai dengan Rp. 5000 (lima ribu rupiah). Koin inilah yang dijadikan sebagai alat pembayaran di Floating Market Lembang. Untuk melihat keabsahannya dalam jual beli harus memenuhi beberapa syarat terkait harga, di antaranya seperti; harga ataupun jumlah yang disepakati kedua belah pihak, diserahkan pada waktu akad, dan nilai tukar dilakukan bukan untuk barang yang diharamkan oleh syara'. Berikut penjelasannya:

1. Harga yang disepakati kedua belah pihak harus jelas jumlahnya.

Bahwa dalam prakteknya setiap makanan ataupun minuman yang dijual di Floating Market Lembang ini pedagang telah mematok harganya dengan koin. Adapun 
terkait harga per koin yang senilai dengan dua ribu rupiah ini disepakati oleh penjual maupun pembeli.

Hal ini dibuktikan oleh penjual yang mengatakan bahwa penetapan harga dalam koin ini, yang senilai dengan Rp. 5000 (lima ribu rupiah) dikarenakan lebih efisien. Sementara pembeli juga menyetujuinya. Menurut salah satu pembeli yang bernama Joko Suwono, mengatakan bahwa penetapan harga ini efisien karena mengingat harga Rp. 5000 (lima ribu rupiah) akan memudahkan dalam bertransaksi, yaitu apabila membeli tidak terlalu banyak koin yang diberikan, berbeda halnya jika harga koin dihargai dengan nilai seribu rupiah, karena koin yang diberikan dalam bertransaksi akan terlalu banyak.

2. Dapat diserahkan pada waktu akad.

Bahwa dalam prakteknya koin yang dijadikan alat transaksi pembayaran di Floating Market Lembang ini dilakukan pada saat terjadinya transaksi jual beli yakni pada saat akad berlangsung.

3. Nilai tukar dilakukan bukan untuk barang yang diharamkan oleh syara.

Bahwa nilai tukar ini digunakan untuk transaksi makanan dan minuman tradisional dan bukan untuk sesuatu barang yang diharamkan oleh syarae, seperti bangkai, babi, khamr, dan sebagainya.

Dari beberapa analisis di atas, dapat disimpulkan bahwa koin yang dijadikan alat tukar di Floating Market Lembang ini sudah memenuhi syarat untuk melakukan transaksi jual beli sebagaimana yang terdapat dalam kaidah-kaidah hukum Islam. Dimana Koin telah memenuhi beberapa syarat terkait harga dalam keabsahan jual beli, di antaranya seperti; harga ataupun jumlah yang disepakati kedua belah pihak, diserahkan pada waktu akad, dan nilai tukar dilakukan bukan untuk barang yang diharamkan oleh syara'.

Pada dasarnya jual beli di Floating Market Lembang ini mengandung tujuan yang baik atau maslahah. Bagi pedagang tujuan akad dalam bertransaksi dengan Koin ini yaitu sebagai ladang penghasilan dengan ikut bergabung dalam memberdayakan UMKM (Usaha Mikro Kecil dan Menengah) di Kabupaten Bandung dengan mengangkat budaya tradisional, serta menjadi pasar yang baru ini menjadi sebuah wisata kuliner di Kabupaten Bandung.

Sedangkan bagi pembeli, tujuan akad dalam bertransaksi ialah karena ingin mempertahankan makanan dan minuman tradisional yang sudah jarang untuk ditemui di tengah-tengah perkembangan zaman yang semakin maju.

Dalam hukum muamalat, keridaan dalam transaksi adalah merupakan prinsip. Oleh karena itu, transaksi barulah sah apabila didasarkan kepada keridaan kedua belah pihak. Hal ini sebagaimana yang terjadi di Floating Market Lembang, bahwa transaksi jual beli juga dapat dikatakan sah apabila pihak-pihak yang bertransaksi saling sepakat dan adanya kerelaan dalam bertransaksi dengan menggunakan koin.

Alat tukar Koin menjadi sah apabila disetujui oleh pihak-pihak yang bertransaksi. Adapun penjual dan pembeli di Floating Market Lembang ini sepakat akan penggunaan 
Koin dan harga per koinnya yang senilai dengan Rp 5000 rupiah, karena pada dasarnya Koin ini hanyalah sebagai alat konversi saja, tidak ada penambahan ataupun pengurangan nilai, sehingga tidak merugikan kedua belah pihak.

Hal ini ditandai dari pihak penjual yang bernama Irma, yang mengatakan bahwa ia menjadi pedagang di Floating Market Lembang ini karena alat tukar yang digunakan ialah Koin, bahwa dengan adanya alat tukar tradisional ini menambah omset penjualan Irma dalam setiap bukanya Pasar ini. Sementara pembeli sangat tertarik dengan konsep yang disajikan di Floating Market Lembang yang menggunakan Koin sebagai alat tukarnya. Sebagaimana yang dikatakan pembeli bernama Joko Suwono, yang tertarik mengunjungi Floating Market Lembang karena alat transaksinya yang menggunakan Koin.

Kerelaan kedua belah pihak merupakan prinsip dalam jual beli. Hal ini sesuai dengan kaidah fikih, yaitu:

"Hukum asal dalam transaksi adalah keridhaan kedua belah pihak yang berakad, hasilnya adalah berlaku sahnya yang diakadkan".

Artinya, tidak sah suatu akad apabila salah satu pihak dalam keadaan terpaksa atau dipaksa atau juga merasa tertipu. Bisa terjadi pada waktu akad sudah saling meridhai, tetapi kemudian salah satu pihak merasa tertipu, artinya hilang keridhaannya, maka akad tersebut bisa batal. Untuk dapat dikatakan kedua belah pihak saling meridhai maka harus memenuhi syarat-syarat keridhaan sebagai berikut:

1. Keridhaan tersebut tidak bertentangan dengan syara'. Bahwa akad yang diridhai oleh kedua belah pihak dalam bertransaksi di Floating Market Lembang ini ialah meridhai jual beli dengan alat tukar koin untuk membeli makanan dan minuman tradisional dan bukan untuk meridhai akad-akad yang diharamkan oleh oleh syara', misalnya kedua belah pihak saling meridhai jual beli babi, jual beli khamr, dan lain sebagainya. Sebagaimana kaidah fikih, yaitu:

Setiap benda yang telah diharamkan Allah Swt, kepada hambaNya, maka memperjualbelikannya adalah haram, karena haram memakan ladang darinya.

Adapun pengertian dari kaidah di atas, yaitu bahwa apa saja yang telah diharamkan oleh Allah Swt seperti arak (khamr), daging anjing, daging babi, dan lain sebagainya, maka diharamkan pula memperjualbelikannya sekaligus memanfaatkannya.

2. Tidak berlawanan dengan tujuan akad. Bahwa tujuan akad jual beli dengan alat tukar koin ialah sama halnya dengan tujuan jual beli pada umumnya yaitu untuk berpindahnya kepemilikan barang dari tangan penjual kepada pembeli tanpa adanya syarat tertentu.

3. Tidak ditemukannya sebab menurut syara' yang menghilangkan atau menggugurkan keridhaan. Bahwa dalam prakteknya di Floating Market Lembang ini para pihak penjual dan pembeli sepakat menggunakan koin sebagai alat transaksinya, karena pada dasarnya koin hanya sebagai alat konversi tanpa mengurangi atau 
menambahkan nilai pada koin tersebut, sehingga para pihak secara suka rela dan tidak terpaksa.

Dari beberapa analisis di atas, dapat disimpulkan bahwa jual beli dengan alat tukar koin di Floating Market Lembang ialah sah karena telah memenuhi syarat-syarat keridhaan; seperti keridhaan tidak bertentangan dengan syara', tidak berlawanan dengan tujuan akad, dan tidak ditemukannya sebab menurut syara'.

Namun, karena koin ini hanya berlaku di Floating Market Lembang, maka keabsahan jual beli dengan alat tukar koin ini hanya berlaku untuk Floating Market Lembang dan bukan berlaku secara keseluruhan untuk masyarakat umum.

Bahwa jual beli dengan alat tukar bukan uang, bukanlah pertama kali terjadi, melainkan pernah terjadi pada masa Nabi Muhammad Saw, yaitu Umar bin Khattab yang pernah mengatakan: "Aku ingin suatu saat menjadikan kulit unta sebagai alat tukar". Bahwa mata uang dapat dibuat dari benda apa saja, dengan syarat benda tersebut telah disepakati sebagai mata uang yang sah, maka barang tersebut telah berubah fungsinya menjadi barang yang bisa menjadi alat tukar.

\section{SIMPULAN}

Setelah dilakukan kajian, analisis, dan pembahasan pada bab sebelumnya atas permasalahan yang dirumuskan dan sesuai dengan tujuan penelitian. Dapat ditarik kesimpulan sebagai berikut:

1. Pelaksanaan jual beli dengan alat tukar koin di Pasar Floating Market merupakan pasar yang menggunakan koin sebagai alat tukarnya. Dimana pembeli yang hendak melakukan transaksi di Floating Market Lembang diharuskan untuk menukarkan uangnya dengan koin. Dalam prakteknya satu koin dihargai dengan nilai Rp. 5000 (lima ribu rupiah). Dalam penjualannya pedagang telah mematok.

2. Harga dalam setiap makanan dan minuman dengan harga koin. Kemudian koin yang ada pada penjual dapat ditukarkan (dikonversikan) kembali ke dalam bentuk uang rupiah kepada pengelola di Floating Market Lembang.

3. Menurut tinjauan fikih muamalah terhadap pelaksanaan jual beli dengan alat tukar di Floating Market Lembang telah menerapkan asas-asas muamalat yaitu mubah, asas kerelaan (antarodin), selain itu pelaksanaannya telah memenuhi rukun dan syarat dalam jual beli, serta tidak mengandung unsur gharar dan menjaga maqasid syariah. Oleh karena itu penelitian jual beli dengan alat tukar koin ini ialah bersifat sah. Namun, karena koin ini hanya berlaku di Floating Market Lembang, maka keabsahan ini hanya berlaku untuk Floating Market Lembang dan bukan berlaku secara keseluruhan untuk masyarakat umum. 


\section{REFERENSI}

Abu Habieb, Sa'di, Ensikopedi Ijmak, Jakarta: Pustaka Firdaus, 1997.

Agama RI, Departemen Al-Qur'an dan Terjemahanya, Jakarta: Pustaka Al-Mubin.

Anshori, Abdul Ghofur, Hukum Islam Dinamika Dan Perkembangannya di Indonesia, Yogyakarta: Kreasi Total Media, 2008.

Aravik, Havis, Sejarah Pemikiran Ekonomi Islam Kontemporer, Jakarta: Kencana, 2007.

Aravik, Havis, Ekonomi Islam, Malang: Empat Dua, 2016.

Ardhy, “Kreweng Jadi Alat Pembayaran di Minggon Jatinan”, Berita Daerah Batang, 15 Juli 2018.

Anwar, Syamsul, Hukum Perjanjian Syariah: Studi tentang Teori Akad dalam Fikih Muamalat, Jakarta: PT.Raja Grafindo Persada, 2007.

Bagong, dan Sutinah, Metode Penelitian Sosial: Berbagai Alternatif Pendekatan, Jakarta: Kencana, 2011.

Chaudry, Muhammad Sharif, Sistem Ekonomi Islam Prinsip dasar, Surabaya: Kencana Prenada Media Group, 2011.

Djazuli, Kaidah-Kaidah Fikih: Kaidah-kaidah Hukum Islam dalam Menyelesaikan Masalah-Masalah yang Praktis, Jakarta: Kencana Prenada Media Group, 2007.

Edwin Nasution, Mustafa, Pengenalan Ekslusif Ekonomi Islam, Jakarta: Kencana Media Group, 2007.

Hakim, Lukman, Prinsip-prinsip Ekonomi Islam, Bandung: Penerbit Erlangga, 2011. 